\title{
Interannual variations of water vapor in the tropical upper troposphere and the lower and middle stratosphere and their connections to ENSO and QBO
}

\author{
Edward W. Tian ${ }^{1,2}$, Hui Su ${ }^{1}$, Baijun Tian ${ }^{1}$, and Jonathan H. Jiang ${ }^{1}$ \\ ${ }^{1}$ Jet Propulsion Laboratory, California Institute of Technology, Pasadena, CA, USA \\ ${ }^{2}$ Department of Economics, University of California, Santa Cruz, CA, USA
}

Correspondence: Jonathan Jiang (jonathan.h.jiang@jpl.nasa.gov)

Received: 24 September 2018 - Discussion started: 5 December 2018

Revised: 9 July 2019 - Accepted: 11 July 2019 - Published: 7 August 2019

\begin{abstract}
In this study, we analyze the Aura Microwave Limb Sounder water vapor data in the tropical upper troposphere and the lower and middle stratosphere (UTLMS) (from 215 to $6 \mathrm{hPa}$ ) for the period from August 2004 to September 2017 using time-lag regression analysis and composite analysis to explore the interannual variations of tropical UTLMS water vapor and their connections to El NiñoSouthern Oscillation (ENSO) and quasi-biennial oscillation (QBO). Our analysis shows that the interannual tropical UTLMS water vapor anomalies are strongly related to ENSO and QBO which together can explain more than half $(\sim 50 \%-60 \%)$ but not all variance of the interannual tropical water vapor anomalies. We find that ENSO's impact is strong in the upper troposphere $(\sim 215-\sim 120 \mathrm{hPa})$ and near the tropopause $(\sim 110-\sim 90 \mathrm{hPa})$, with a $\sim 3$-month lag but weak in the lower and middle stratosphere $(\sim 80$ to $\sim 6 \mathrm{hPa})$. In contrast, QBO's role is large in the lower and middle stratosphere, with an upward-propagating signal starting at the tropopause $(100 \mathrm{hPa})$ with a $\sim 2$-month lag, peaking in the middle stratosphere near $15 \mathrm{hPa}$ with a $\sim 21$-month lag. The phase lag is based on the $50 \mathrm{hPa}$ QBO index used by many previous studies. This observational evidence supports that the QBO's impact on the tropical stratospheric water vapor is from its modulation on the tropical tropopause temperature and then transported upward with the tape recorder as suggested by many previous studies. In the upper troposphere, ENSO is more important than QBO for the interannual tropical water vapor anomalies that are positive during the warm ENSO phases but negative during the cold ENSO phases. Near the tropopause, both ENSO and QBO are important for the interannual tropical water vapor anomalies.
\end{abstract}

Warm ENSO phase and westerly QBO phase tend to cause positive water vapor anomalies, while cold ENSO phase and easterly QBO phase tend to cause negative water vapor anomalies. As a result, the interannual tropical water vapor anomalies near the tropopause are different depending on different ENSO and QBO phase combinations. In the lower and middle stratosphere, QBO is more important than ENSO for the interannual tropical water vapor anomalies. For the westerly QBO phases, interannual tropical water vapor anomalies are positive near the tropopause and in the lower stratosphere but negative in the middle stratosphere and positive again above. Vice versa for the easterly QBO phases.

\section{Introduction}

Water vapor (WV) is the dominant greenhouse gas in the atmosphere and plays an important role in global weather and climate systems. Since higher temperature is associated with higher saturation vapor pressure, water vapor has a positive feedback to surface warming. Previous studies indicate that the water vapor feedback is the largest positive feedback in climate models that increases the sensitivity of surface temperature to increasing carbon dioxide (Held and Soden, 2000; Soden and Held, 2006). The middle and upper tropospheric water vapor dominates the water vapor feedback (e.g., Held and Soden, 2000; Riese et al., 2012; Soden et al., 2008). The stratospheric water vapor may account for about $10 \%$ of total water vapor feedback (Dessler et al., 2013). In addition, the water vapor in the stratosphere plays an impor- 
tant role in stratospheric ozone chemistry and global radiative balance (Forster and Shine, 1999; Solomon et al., 2010). Thus, it is important to study the water vapor variability in the upper troposphere and the lower and middle stratosphere (UTLMS).

The water vapor in the tropical upper troposphere is mainly from the tropical lower troposphere through convective transport of water vapor and evaporation of convectively transported or in situ produced cloud ices (e.g., $\mathrm{Su}$ et al., 2006; Tian et al., 2004). The majority of the water vapor in the tropical lower and middle stratosphere (LMS) is from the tropical upper troposphere through the tropical tropopause. The tropical LMS water vapor concentration is thus mainly determined by the tropical tropopause $(\sim 100 \mathrm{hPa})$ temperature that regulates the amount of tropical upper tropospheric water vapor entering the tropical stratosphere (e.g., Fueglistaler et al., 2009; Liang et al., 2011; Randel et al., 2004; Zhou et al., 2001, 2004). Part of the water vapor in the tropical LMS is also from the local methane oxidation.

The water vapor in the tropical UTLMS exhibits multitimescale variations ranging from daily to decadal (e.g., Fueglistaler et al., 2009; Fujiwara et al., 2010; Hegglin et al., 2014; Jiang et al., 2015; Mote et al., 1996; Schwartz et al., 2008; Solomon et al., 2010; Tian et al., 2004, 2006, 2010). In particular, large interannual variations of water vapor in the tropical UTLMS have been observed and shown to be important for both climate and chemical reasons (e.g., Dessler et al., 2013, 2014; Fueglistaler and Haynes, 2005; Liang et al., 2011; Liess and Geller, 2012; Randel and Jensen, 2013; Tao et al., 2015; Ye et al., 2018). Several well-known interannual climate variabilities and their interactions are found to modulate the interannual variations of tropical UTLMS water vapor, such as the El Niño-Southern Oscillation (ENSO) (e.g., Dessler et al., 2014; Liang et al., 2011; Randel et al., 2004; Su and Jiang, 2013; Ye et al., 2018), the quasi-biennial oscillation (QBO) (e.g., Dessler et al., 2014; Fueglistaler and Haynes, 2005; Geller et al., 2002; Kawatani et al., 2014; Liang et al., 2011; Liess and Geller, 2012; Randel et al., 2004; Randel and Jensen, 2013; Tao et al., 2015; Ye et al., 2018), and the interannual variations in the strength of the Brewer-Dobson circulation (BDC) (e.g., Dessler et al., 2013, 2014; Randel et al., 2006; Ye et al., 2018).

The BDC is a slow stratospheric mean meridional circulation in which air parcels rise in the tropics, drift poleward into the stratosphere, and are transported downward in the high-latitude regions via its shallow and deep branches (Brewer, 1949; Butchart, 2014). The BDC is one of the few truly global-scale phenomena observed in the Earth's atmosphere below $\sim 50 \mathrm{~km}$. It is particularly prominent because of its widespread controlling influence on the stratosphere. For instance, it has important roles in determining the thermodynamic balance of the stratosphere, the temperature of the tropical tropopause, the water vapor entry into the stratosphere, the period of the tropical QBO, the life- times of CFCs and some greenhouse gases, and the transport and redistribution within the stratosphere of greenhouse gases, ozone, aerosols, and volcanic and radioactive debris (Butchart, 2014). Driven by wave breaking in the stratosphere, the BDC varies on subseasonal to decadal timescales.

The QBO is a major mode of interannual variability in the tropical upwelling of the BDC (Baldwin et al., 2001; Lindzen and Holton, 1968). The QBO describes the quasi-biennial oscillation of downward-propagating easterly or westerly zonal winds in the equatorial stratosphere from the middle stratosphere to the tropopause with a period of $\sim 28$ months (Baldwin et al., 2001). It is well known that the QBO causes large-scale circulation changes that affect ozone, water vapor, methane and global weather and climate. The QBO's impact on the tropical UTLMS water vapor is mainly through the QBO's influence on the tropical tropopause temperature that regulates the amount of upper tropospheric water vapor entering the stratosphere (e.g., Fueglistaler et al., 2009; Fujiwara et al., 2010; Geller et al., 2002; Kawatani et al., 2014; Liang et al., 2011; Randel et al., 2004; Zhou et al., 2001, 2004). Mostly driven by equatorially trapped waves, the QBO triggers an anomalous meridional circulation in the stratosphere between the tropics and subtropics (from the Equator to $30^{\circ} \mathrm{N}$ and $30^{\circ} \mathrm{S}$ ) to maintain the thermal wind balance between the descending QBO wind shear and its temperature anomaly (Diallo et al., 2018; Tweedy et al., 2017). At the Equator, westerly shear (westerlies aloft and easterlies below) is in balance with a downwardpropagating and adiabatically warmed perturbation, while easterly shear (easterlies aloft and westerlies below) produces an upward-propagating and adiabatically cooled perturbation. The tropical upwelling perturbation is anticorrelated with the tropical temperature perturbation in the lower stratosphere. The enhanced upwelling during easterly shear and reduced upwelling during westerly shear in the tropics are mass balanced by the changes in the subtropical descent. The circulation is "completed" by the equatorial divergence/convergence of air at the levels of maximum easterly/westerly winds (Choi et al., 2002). As the westerly shear reaches the tropopause, it warms the tropopause and increases the amount of the upper tropospheric water vapor entering the lower stratosphere. Conversely, as the easterly shear reaches the tropopause, it cools the tropopause and decreases the amount of the upper tropospheric water vapor entering the lower stratosphere (Diallo et al., 2018; Tweedy et al., 2017). It is also noted that the QBO modulates the extratropical wave activity, an important driver for the BDC, which influences the tropical cold point tropopause temperature.

ENSO is the interannual oscillation (2-7-year) of sea surface temperatures (SSTs) and easterly trade winds in the tropical Pacific Ocean caused by the coupled interactions between the ocean and atmosphere (Wallace et al., 1998). It is the primary source of global interannual climate variabilities (Philander, 1990; Wallace et al., 1998). During a warm ENSO (El Niño) phase, trade winds are weaker and warm 
waters move eastward to the equatorial central and eastern Pacific. During a cold ENSO (La Niña) phase, trade winds are stronger and warm waters move further westward to the equatorial western Pacific. ENSO can modulate the tropical UTLMS water vapor through several physical and dynamical processes, such as convective transport of tropospheric water vapor, evaporation of cloud ice, and the perturbations of the tropical tropopause $(\sim 100 \mathrm{hPa})$ temperature (e.g., Dessler et al., 2014; Gettelman et al., 2001; Liang et al., 2011; Ye et al., 2018; Zhou et al., 2001, 2004). In the tropical upper troposphere, ENSO modulates the water vapor mainly through the convective transport of lower tropospheric water vapor and evaporation of cloud ice. In the stratosphere including the tropopause region, ENSO modulates the water vapor mainly through its influence on the tropical tropopause temperature that regulates the amount of water vapor entering the stratosphere. From a zonal mean perspective, El Niño events induce a tropospheric warming and a stratospheric cooling with a node near the tropopause, strengthen the tropical upwelling of the BDC, and decrease the tropical lower stratospheric ozone (Calvo et al., 2010; Randel et al., 2009). Lower stratospheric water vapor, however, is predominantly controlled by cold point temperatures over the tropical western Pacific (Avery et al., 2017; Diallo et al., 2018). El Niño events are associated with warmer cold point temperatures over this region, thereby causing increased lower stratospheric water vapor (e.g., Avery et al., 2017; Calvo et al., 2010; Konopka et al., 2016). In contrast, La Niña events induce an opposite effect.

Many previous studies have significantly improved our knowledge about the interannual variations of the tropical UTLMS water vapor. For example, Liang et al. (2011) studied the atmospheric water vapor and temperature variability in the tropical UTLMS using a merged Aqua Atmospheric Infrared Sounder (AIRS) and Aura Microwave Limb Sounder (MLS) temperature and water vapor record (August 2004 to March 2010). They found that both ENSO and QBO impact the tropical tropopause water vapor and the water vapor anomalies near the tropical tropopause are strongly dependent on the alignment of ENSO and QBO phases. Dessler et al. $(2013,2014)$ performed a multi-linear regression of the tropical lower stratospheric $(82 \mathrm{hPa})$ water vapor variability to the $\mathrm{QBO}, \mathrm{BDC}$ and tropospheric temperature (which is correlated with ENSO). They found that the tropical lower stratospheric water vapor lags QBO by about 3 months and lags BDC by 1 month based on the $50 \mathrm{hPa}$ QBO index. Ye et al. (2018) performed a two-dimensional multivariate linear regression of the tropical tropopause water vapor interannual variability to the QBO, BDC and tropospheric temperature as a function of latitude and longitude based on satellite observations and model simulations. They found that the evaporation of convective ice from increased deep convection as the troposphere warms plays an important role in the tropopause water vapor variability in addition to changing tropopause temperature. Ding and Fu (2018) found that the tropical central Pacific SST warming contributes significantly to enhanced convection and thus a sudden drop of the lower stratospheric $(83 \mathrm{hPa})$ water vapor around 2000 . They suggested that the tropical central Pacific SST is another important driver of the lower stratospheric water vapor variability on inter-decadal timescales.

During the boreal winter 2015-2016, a strong El Niño event (among the three strongest El Niño events on record) (Huang et al., 2016) was aligned with a westerly QBO phase. This westerly QBO phase was abruptly disrupted well before completion by an easterly phase in January 2016 (Newman et al., 2016; Osprey et al., 2016). The interplay between both circulation anomalies caused large changes in trace gas transport, the climate implications of which are currently a topic of debate. Avery et al. (2017) argued that the most recent El Niño event significantly moistened the lower stratosphere due to convective ice lofting, with the QBO having only a small contribution. In contrast, Tweedy et al. (2017) attributed the lower stratospheric water vapor changes from spring to autumn to the 2015-2016 QBO disruption. Diallo et al. (2018) showed that the alignment of a strong El Niño event with westerly QBO in the early boreal winter of 2015-2016 substantially increased water vapor in the tropical lower stratosphere (positive anomalies of more than $20 \%$ ). The sudden shift in the QBO from westerly to easterly wind shear significantly decreased global lower stratospheric water vapor from early spring to late autumn and reversed the lower stratosphere moistening to the lower stratosphere drying (negative anomalies of close to $20 \%$ ). They emphasized that the control of the lower stratospheric water vapor anomalies strongly depends on the interactions between ENSO and QBO phases. The interaction of El Niño and the westerly QBO phase leads to large positive lower stratospheric water vapor anomalies, while the interplay between La Niña and the easterly QBO phase leads to negative water vapor anomalies. During weak and moderate ENSO events, the water vapor anomalies are mainly controlled by the QBO phase.

However, the aforementioned studies mainly focused on a few specific levels of the UTLMS layer, either $82 \mathrm{hPa}$ (Dessler et al., 2013, 2014; Ding and Fu, 2018) or $100 \mathrm{hPa}$ (Ye et al., 2018) or based on limited data periods (Avery et al., 2017; Diallo et al., 2018; Liang et al., 2011; Tweedy et al., 2017). A comprehensive investigation of the interannual variations of the tropical water vapor in the whole UTLMS layer with a much longer period and their relationships with ENSO and QBO is still lacking. In addition, the relative importance of ENSO and QBO for the tropical UTLMS water vapor interannual variabilities at different levels has not been well investigated in the previous studies.

This study seeks to investigate the interannual variations of water vapor in the tropical UTLMS layer and their relationships with ENSO and QBO using the Aura MLS UTLMS water vapor data. We are particularly interested in the relative roles of ENSO and QBO in the interannual variations of water vapor in the tropical UTLMS layer at different levels. 
This study distinguishes itself from previous studies in the three following ways. (1) The current study investigates the interannual variations of water vapor in the whole tropical UTLMS layer from 215 to $6 \mathrm{hPa}$ instead of a couple of layers in the previous ones. (2) The Aura MLS UTLMS water vapor data of much longer length (August 2004 to September 2017) are used in the current study than the previous ones. (3) The relative importance of ENSO and QBO on the tropical UTLMS water vapor interannual variabilities for the entire UTLMS layer and at different phase lags is more completely investigated in the current study than the previous ones. (4) This study will present some new observational evidence to better understand the role of ENSO and QBO in the tropical UTLMS water vapor interannual variations, especially regarding the role of $\mathrm{QBO}$ and its tape recorder effect. (5) This study will also present a composite view of the tropical UTLMS water vapor interannual variations based on different combinations of ENSO and QBO phases.

The rest of this paper is organized as follows. Section 2 describes the MLS water vapor data and the analysis methods. Section 3 presents the results, followed by summary and conclusions in Sect. 4.

\section{Data and methods}

We use the Version 4.2 Level 2 daily Aura MLS water vapor volume mixing ratio product as described in Read et al. (2007) and Livesey (2015) from 215 to $6 \mathrm{hPa}$ over the period of August 2004 to September 2017. The MLS water vapor data were averaged to monthly means and gridded onto $2.5 \times 2.5$ horizontal spatial grids. The MLS Level 2 data have a vertical resolution of $\sim 3 \mathrm{~km}$ and horizontal resolutions of $\sim 7 \mathrm{~km}$ across track and $\sim 200-300 \mathrm{~km}$ along track. The useful altitude ranges are at pressure $(p) \leq 316 \mathrm{hPa}$, but we only use the water vapor data above $215 \mathrm{hPa}$ because of larger uncertainty below $215 \mathrm{hPa}$ altitude. The measurement uncertainties (including biases) are $20 \%$ in the upper troposphere $(p>100 \mathrm{hPa})$ and $10 \%$ near the tropopause $(\sim 100 \mathrm{hPa})$ and in the stratosphere $(p \leq 100 \mathrm{hPa})$ (Lambert et al., 2007; Read et al., 2007). These measurement uncertainties are retrieval uncertainties and are estimated based on (1) the average difference between the simulated retrieval and truth file; and (2) the average difference between MLS measurements and the airborne measurements. These uncertainties should not affect our results because we are interested in the interannual anomalies instead of its means. In addition, Hegglin et al. (2013) show that MLS zonal monthly mean water vapor shows very good to excellent agreement with the multi-instrument mean (MIM) in comparison between 13 instruments, throughout most of the atmosphere (including the UTLS), with mean deviations from the MIM between $+2.5 \%$ and $+5 \%$, making these random errors irrelevant for the average monthly zonal mean water vapor anomalies used in this study (Diallo et al., 2018). The Aura
MLS water vapor data have been used extensively in atmospheric process analysis studies and climate model evaluations (e.g., Dessler et al., 2013, 2014; Flury et al., 2012; Jiang et al., 2012; Liang et al., 2011; Liu et al., 2018; Solomon et al., 2010; Su et al., 2006; Takahashi et al., 2016; Uma et al., 2014; Wu et al., 2012). The MLS water vapor data are freely available through the Aura MLS project website (https://mls.jpl.nasa.gov, last access: 14 August 2018).

Since we are mainly interested in the tropical UTLMS, we first averaged the MLS monthly water vapor data between $15^{\circ} \mathrm{S} / \mathrm{N}$, and along the entire latitude band $\left(\mathrm{wv}_{t, p}\right)$. Then, the tropical mean seasonal cycle ( $\mathrm{wv}_{m, p}, 12$ months) was calculated as the averages of the tropical MLS monthly water vapor data at each calendar month over the whole MLS data record. Next, de-seasonalized monthly tropical water vapor anomalies were obtained by removing the tropical mean seasonal cycle from the tropical monthly water vapor data $\left(\mathrm{wv}_{t, p}^{\prime}=\mathrm{wv}_{t, p}-\mathrm{wv}_{m, p}\right)$. Then, the interannual (2-7 years) tropical water vapor anomalies (or short-handed as anomalies for simplicity) were isolated through the difference between the 12- and 42-month running means of the de-seasonalized monthly tropical water vapor anomalies to remove the highfrequency (e.g., synoptic, seasonal, intraseasonal, and annual) and low-frequency (e.g., solar cycle and decadal) variabilities. Last, the interannual monthly tropical water vapor anomalies were converted into percentage deviations by dividing the interannual monthly tropical water vapor anomalies by the long-term tropical mean $\left(\mathrm{wv}_{p}\right)$ at the respective pressure level. The resulting interannual monthly tropical water vapor anomalies in percentage deviations are used throughout the analysis.

Using the difference of running means of different widths as a band-pass filter is effective. A 12-month running mean will remove the high-frequency variabilities $(<2$ years $)$ and keep the interannual variability (2-7 years) and the low-frequency variabilities ( $>7$ years). A 42-month running mean will remove the high-frequency variabilities $(<2$ years $)$ and the interannual variability $(2-7$ years $)$ and keep the low-frequency variabilities ( $>7$ years). As a result, the difference between the 12- and 42-month running means will remove both the high-frequency $(<2$ years) and low-frequency ( $>7$ years) variabilities and keep the interannual variability (2-7 years) only. This simple approach of the band-pass filter has been used in the previous studies related to the Madden-Julian Oscillation (e.g., Tian et al., 2006, 2007, 2011).

To represent ENSO phases, we use a bimonthly multivariate ENSO index (MEI) downloaded from the National Oceanic and Atmospheric Administration (NOAA) Earth System Research Laboratory (ESRL) website (https://www. esrl.noaa.gov/psd/enso/mei/, last access: 29 July 2019). After spatially filtering the individual fields into clusters, the MEI is calculated as the first unrotated principal component (PC) of all six observed fields combined, including sealevel pressure, zonal and meridional surface winds, sea sur- 
face temperature, surface air temperature, and total cloudiness over the tropical Pacific collected and published in the International Comprehensive Ocean-Atmosphere Data Set (ICOADS) (Wolter and Timlin, 2011). Positive MEI values indicate warm ENSO (El Niño) phases, while negative MEI values indicate cold ENSO (La Niña) phases. In order to keep the MEI comparable, all seasonal values are standardized with respect to each season and to the 1950-1993 reference period. The MEI is computed separately for each of 12 sliding bi-monthly seasons (December/January, January/February, November/December). We use the MEI value of month $(i-1)$ and month $(i)$ as if it were the value for month $(i)$ only as advised by the NOAA MEI website.

For QBO, we use the standardized anomaly of monthly zonal mean zonal wind at the Equator and $50 \mathrm{hPa}\left(u_{50}\right.$, $\mathrm{m} \mathrm{s}^{-1}$ ) based on the National Centers for Environmental Prediction (NCEP)/National Center for Atmospheric Research (NCAR) reanalysis (CDAS) downloaded from the NOAA NCEP Climate Prediction Center (CPC) website (http:// www.cpc.ncep.noaa.gov/data/indices/qbo.u50.index, last access: 29 July 2019). Positive $u_{50}$ values denote westerly QBO phases, while negative $u_{50}$ values denote easterly QBO phases. This $50 \mathrm{hPa}$ QBO index has been frequently used by previous studies (Dessler et al., 2013, 2014; Ye et al., 2018). The ENSO and QBO indices from August 2004 to September 2017 are shown in Fig. 1.

With the ENSO, QBO, and MLS data sets we conducted two types of analysis: lead-lag regression analysis and composite analysis. The lead-lag regression identifies how much time lag exists between the perturbation of a climate mode and the response of the UTLMS water vapor anomalies at different pressure levels. We normalized each index by dividing each index anomaly by its standard deviation before performing the linear regressions. For every pressure level and time shift, a univariate linear regression is performed first with respect to either ENSO or QBO index individually $\left(\mathrm{WV}=\mathrm{X}_{0}+\mathrm{X}_{1} \times \mathrm{ENSO}\right.$ and $\left.\mathrm{WV}=\mathrm{X}_{0}+\mathrm{X}_{1} \times \mathrm{QBO}\right)$. The respective $R^{2}$ value of each linear regression, a standard measure of proportion of explained variance, is used to indicate how much water vapor variability can be described by each linear regression separately for each pressure level and time lag. The maximum $R^{2}$ value will determine the optimal time lag for the univariate linear regression at each pressure level. A multivariate linear regression with respect to ENSO and QBO together is then performed using the optimal time lags obtained from the univariate linear regressions to estimate how much water vapor variability can be described by ENSO and QBO combined. The residual between the original observation and the multivariate linear regression with respect to ENSO and QBO together is also calculated to quantify how much water vapor variability cannot be explained by ENSO and QBO together and may be due to nonlinear or coupled ENSO-QBO interaction and other physical processes (e.g., BDC). We recognize that using the $R^{2}$ value of a linear regression as a proportion of explained variance is based on the following strong assumption: the UTLMS water vapor interannual anomaly is a linear function of ENSO or QBO index with a Gaussian distribution. Within the observed interannual anomalies of the UTLMS water vapor and climate variabilities, these assumptions are not perfect, but are useful.

For the composite analysis, we first partitioned the interannual monthly MLS water vapor anomalies into four different cases based on different combinations of ENSO and QBO phases: warm ENSO (MEI > 0.3) and westerly QBO $\left(u_{50}>\right.$ $0.1 \mathrm{~m} \mathrm{~s}^{-1}$ ) case, warm ENSO (MEI $>0.3$ ) and easterly QBO $\left(u_{50}<-0.1 \mathrm{~m} \mathrm{~s}^{-1}\right)$ case, cold ENSO (MEI $<-0.3$ ) and westerly QBO $\left(u_{50}>0.1 \mathrm{~m} \mathrm{~s}^{-1}\right)$ case, and cold ENSO $(\mathrm{MEI}<-0.3)$ and easterly QBO $\left(u_{50}<-0.1 \mathrm{~m} \mathrm{~s}^{-1}\right)$ case. These threshold values were chosen in order to remove the ENSO and QBO neutral phases and have sufficient samples for the composites at the same time. We then averaged the interannual monthly MLS water vapor anomalies for each case to create a composite mean profile. The composite analysis was applied to the MLS interannual water vapor anomaly data for annual means, the summer months (MJJASO) average and the winter months (NDJFMA) average separately.

\section{Results}

Figure 2 shows the interannual monthly mean tropical water vapor anomalies from MLS in percentage deviations at different pressure levels from 215 to $6 \mathrm{hPa}$ and from $\mathrm{Au}$ gust 2004 to September 2017. In the upper troposphere from $\sim 215$ to $\sim 120 \mathrm{hPa}$, large vertically oriented tropical water vapor anomalies of $\pm 15 \%$ are evident. They seem to be coincident with several El Niño or La Niña events shown in Fig. 1, with positive anomalies during the warm ENSO phases and negative anomalies during the cold ENSO phases. In the lower and middle stratosphere (100-6 hPa), large tropical water vapor anomalies of $\pm 15 \%$ are found to propagate upward at a speed of about $7 \mathrm{~km} \mathrm{yr}^{-1}$ starting around $100 \mathrm{hPa}$ with a first local maximum in the lower stratosphere around $68 \mathrm{hPa}$ and a second local maximum in the middle stratosphere around $15 \mathrm{hPa}$. These have been referred to as the interannual variability of the stratospheric water vapor tape recorder (e.g., Geller et al., 2002; Kawatani et al., 2014; Liang et al., 2011) and are regulated by QBO. The small interannual water vapor anomalies at the beginning and ending months of the data record are results of the boundary effect of using the difference of running means as a band-pass filter.

To show the relative importance of ENSO and QBO and their roles in the interannual tropical water vapor anomalies at different pressure levels, Fig. 3 shows the $R^{2}$ values for the linear regressions between the MLS tropical UTLMS interannual monthly water vapor anomalies and the ENSO or QBO index from 215 to $6 \mathrm{hPa}$ with time-lag shifts from 0 to 24 months. Figure $3 \mathrm{a}$ (left) is for ENSO $\left(\mathrm{WV}=\mathrm{X}_{0}+\mathrm{X}_{1} \times \mathrm{ENSO}\right)$ and Fig. 3b (right) is for QBO $\left(\mathrm{WV}=\mathrm{X}_{0}+\mathrm{X}_{1} \times \mathrm{QBO}\right)$. The time-lag shift indicates the 


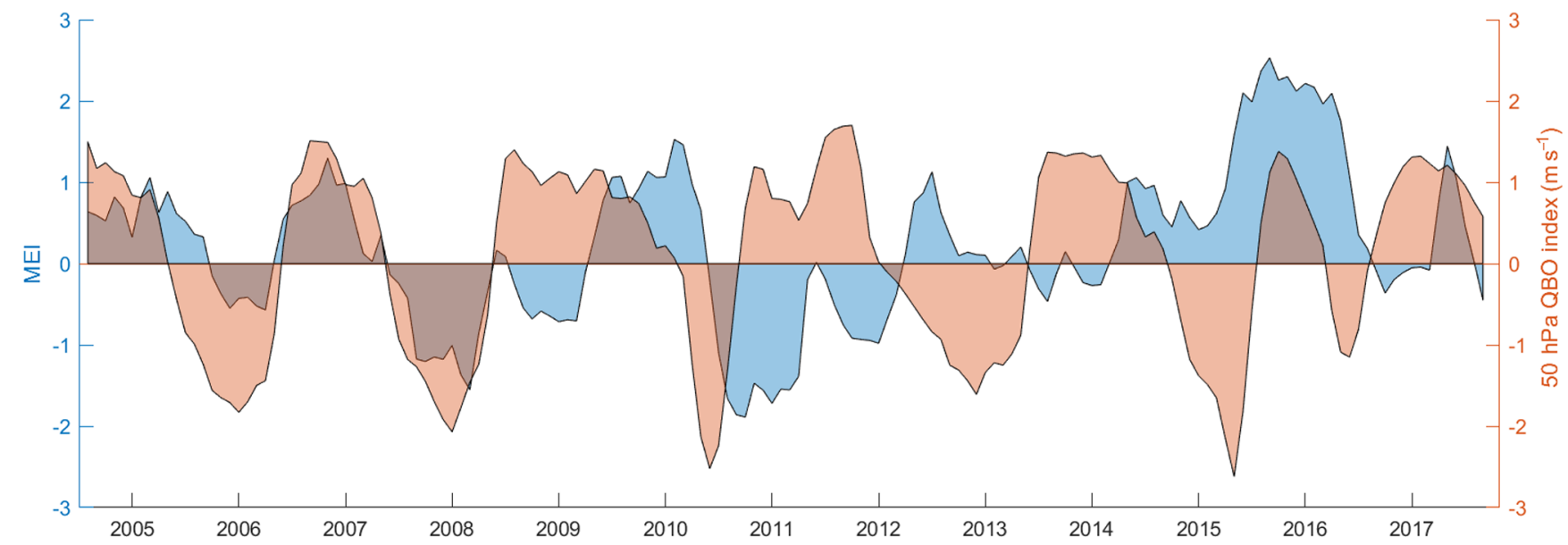

Figure 1. Bimonthly multivariate ENSO index (MEI, blue) and monthly $50 \mathrm{hPa}$ QBO index $\left(u_{50}, \mathrm{~m} \mathrm{~s}^{-1}\right.$, orange) based on the standardized anomaly of monthly zonal mean zonal wind at the Equator and $50 \mathrm{hPa}$, both from NOAA at the period from August 2004 to September 2017. Positive MEI values indicate warm ENSO (El Niño) phases, while negative MEI values indicate cold ENSO (La Niña) phases. Positive $u_{50}$ values denote westerly QBO phases, while negative $u_{50}$ values denote easterly QBO phases.

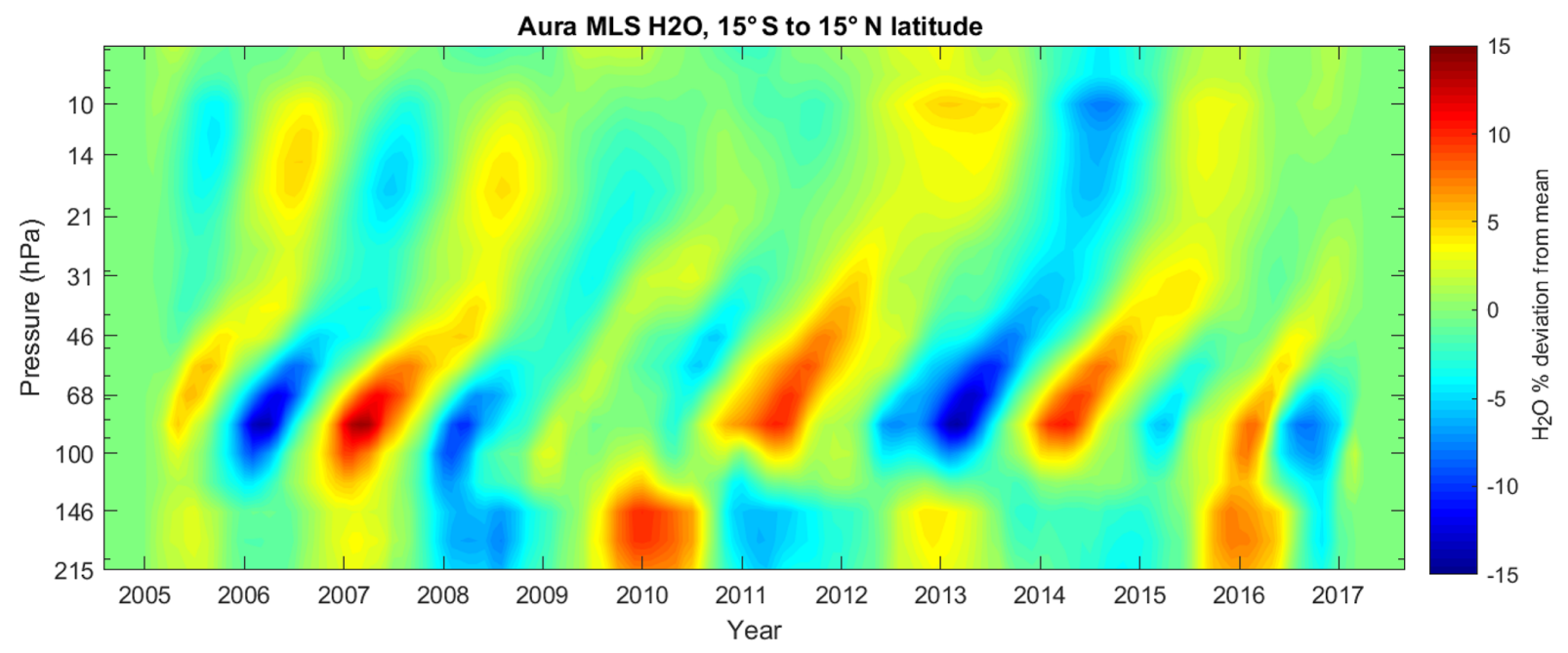

Figure 2. Monthly interannual tropical water vapor anomalies from MLS in percentage deviations at different pressure levels from August 2004 to September 2017.

number of months that the tropical water vapor anomalies lag the ENSO or QBO index. The maximum time lag of 24 months was chosen due to the fact that 24 months are close to the period of a QBO cycle and the minimum period of an ENSO cycle. Figure 3a indicates the $R^{2}$ value for the linear regressions between the tropical water vapor anomalies and the ENSO index is large $(\sim 0.5)$ in the upper troposphere, becomes smaller $(\sim 0.1)$ at the tropopause $(\sim 100 \mathrm{hPa})$ and is very small (close to zero) in the stratosphere above $80 \mathrm{hPa}$. This is consistent with the large vertically oriented water vapor anomalies of $\pm 15 \%$ in the upper troposphere that are coincident with several El Niño or La Niña events shown in Fig. 2. This implies that ENSO has a strong impact on the water vapor interannual variability in the upper troposphere and around the tropopause, while its impact on the water vapor interannual variability is very small in the stratosphere. The current finding of the strong impact of ENSO on the water vapor in the upper troposphere and around the tropopause is consistent with several previous studies (Dessler et al., 2014; Gettelman et al., 2001; Liang et al., 2011; Ye et al., 2018) that suggested ENSO can strongly modulate the upper tropospheric water vapor through the convective transport of tropospheric water vapor and the evaporation of cloud ice. In terms of the response time, the highest correlation is at an $\sim 3$-month lag. This is comparable to the tropospheric temperature response time to the ENSO SST anomaly (Su et al., 2005). The current finding of the weak influence of ENSO on the water vapor anomalies 

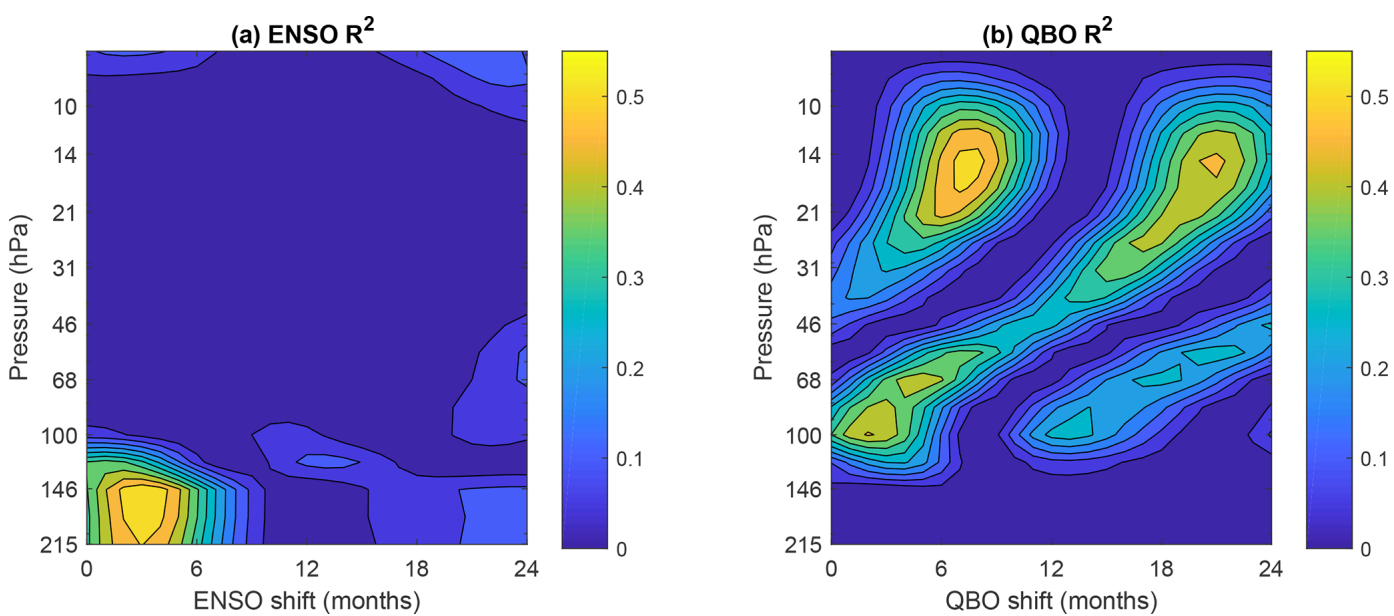

Figure 3. $R^{2}$ values for the linear regressions between the interannual tropical water vapor anomalies from MLS and the ENSO or QBO index at each pressure level with time-lag shifts from 0 to 24 months. (a) is for ENSO (WV $\left.=\mathrm{X}_{0}+\mathrm{X}_{1} \times \mathrm{ENSO}\right)$ and (b) is for QBO $\left(\mathrm{WV}=\mathrm{X}_{0}+\mathrm{X}_{1} \times \mathrm{QBO}\right)$. The time-lag shift indicates the number of months that interannual tropical water vapor anomalies lag the ENSO or QBO index.

in the lower and middle stratosphere is also consistent with a previous study (Ding and $\mathrm{Fu}, 2018$ ) that suggested the small effect of ENSO on tropical zonal mean lower stratospheric water vapor is due to the opposite phases of lower stratospheric water vapor anomalies in response to ENSO in the longitudinal direction. This is due to the compensating effect of ENSO on the tropical tropopause temperature anomalies between the western equatorial Pacific and the central equatorial Pacific that reduces the zonal mean tropical tropopause temperature anomalies found by previous studies (Avery et al., 2017; Gettelman et al., 2001; Kiladis et al., 2001; Liang et al., 2011).

For the linear regressions between the interannual tropical water vapor anomalies and the QBO index, Fig. 3b indicates that the QBO influence is small in the upper troposphere but large in the lower and middle stratosphere. The high $R^{2}$ value between the tropical water vapor anomalies and the $50 \mathrm{hPa}$ QBO index starts at the tropopause at a time lag of $\sim 2$ months and propagates upwards, peaking in the middle stratosphere at $\sim 15 \mathrm{hPa}$ with a time lag of $\sim 21$ months and disappearing at about $6 \mathrm{hPa}$. The $R^{2}$ value is large $(\sim 0.5)$ at the tropopause at a time lag of $\sim 2$ months. Above $100 \mathrm{hPa}$, it first decreases to about 0.3 at about $40 \mathrm{hPa}$ at a time lag of $\sim 13$ months. Above $40 \mathrm{hPa}$, it then increases to about 0.5 in the middle stratosphere at about $15 \mathrm{hPa}$ with a time lag of $\sim 21$ months (a local peak). Above $15 \mathrm{hPa}$, it then decreases again till it disappears at about $6 \mathrm{hPa}$. The peak at $\sim 15 \mathrm{hPa}$ with a time lag of $\sim 8$ months is the result of the upwardpropagating signal starting at the tropopause at a time lag of a few months earlier than the $50 \mathrm{hPa}$ QBO index. These phase lags are consistent with the findings of previous studies (Dessler et al., 2013, 2014; Ye et al., 2018). The time lag of $\sim 2$ months for the high correlation between the tropical tropopause water vapor anomalies and the $50 \mathrm{hPa}$ QBO index is similar to the time needed for the QBO signal to propagate downward from the $50 \mathrm{hPa}$ level to the tropopause (Tweedy et al., 2017). The above vertical structure of the high $R^{2}$ value for the linear regressions between the tropical water vapor anomalies and the $50 \mathrm{hPa} \mathrm{QBO}$ index suggests that the QBO does not directly affect the water vapor concentration at altitudes higher than $100 \mathrm{hPa}$; instead, the QBO signal in the tropical LMS water vapor is imprinted at the tropopause (about $100 \mathrm{hPa}$ ) first, and then it is transported upward with the tape recorder. This observational evidence supports the QBO's impact on the stratospheric water vapor being from its modulation on the tropical tropopause temperature, as suggested by many previous studies (e.g., Diallo et al., 2018; Fueglistaler et al., 2009; Liang et al., 2011; Randel et al., 2004; Tweedy et al., 2017; Zhou et al., 2001, 2004). This is also consistent with the upward-propagating tropical water vapor anomalies of $\pm 15 \%$ in the lower and middle stratosphere shown in Fig. 2 and is referred to as the interannual variability of the stratospheric water vapor tape recorder (e.g., Geller et al., 2002; Liang et al., 2011). This indicates that the interannual variability of the stratospheric water vapor tape recorder (e.g., Geller et al., 2002; Liang et al., 2011) is a result of the impact of QBO. It is possible that the interannual variations of the BDC play a role here too because the QBO modulates the extratropical wave activity, an important driver for the BDC, which influences the tropical cold point tropopause temperature.

Between about $120 \mathrm{hPa}$ and about $40 \mathrm{hPa}$, the decrease in the high $R^{2}$ value with altitude can be easily understood by mixing or dilution of the upward transport of the imprinted $100 \mathrm{hPa}$ signal by the tape recorder. However, the increase in the high $R^{2}$ value between 40 and $15 \mathrm{hPa}$ and the peak of the high $R^{2}$ value at about $15 \mathrm{hPa}$ cannot easily be explained by the tape recorder only. Other sources, such as the 
downward propagation of water vapor anomalies in the upper stratosphere due to the methane oxidation, may be responsible for this phenomenon (Kawatani et al., 2014).

Figure 4 shows the time series of the monthly interannual tropical MLS water vapor anomalies (blue lines) and the predicted interannual monthly tropical water vapor anomalies based on the univariate linear regressions on the ENSO index only (red lines) or the QBO index only (orange lines) at the time lag less than 12 months with the highest $R^{2}$ value for four specific pressure levels, 147, 100, 68, and $15 \mathrm{hPa}$, representing the upper troposphere, tropopause, lower stratosphere, and mid-stratosphere, respectively. Figure 4 reaffirms the results shown in Fig. 3: the decreasing contributions of ENSO and the increasing contributions of QBO to the interannual variability of UTLMS water vapor as the altitude increases. The $R^{2}$ value for the linear regressions between the MLS interannual tropical water vapor anomalies and the ENSO index is $\sim 0.54$ at the $147 \mathrm{hPa}$ altitude with $\mathrm{a} \sim 3$ month time lag and $\sim 0.08$ at the tropopause with a $\sim 11$ month time lag, and deceases to $\sim 0.01$ at the $68 \mathrm{hPa}$ altitude with a $\sim 12$-month time lag and $\sim 0.02$ at the $15 \mathrm{hPa}$ altitude with a $\sim 6$-month time lag. In contrast, the $R^{2}$ value for the linear regressions between the MLS interannual tropical water vapor anomalies and the QBO index is small $(\sim 0.03)$ at the $147 \mathrm{hPa}$ altitude with a $\sim 0$-month time lag, becomes significant and large $(\sim 0.46)$ at the tropopause with a $\sim 2$ month time lag, $\sim 0.44$ at the $68 \mathrm{hPa}$ altitude with a $\sim 5$ month time lag, and $\sim 0.52$ at the $15 \mathrm{hPa}$ altitude with a $\sim 8$-month time lag. Therefore, for the interannual variability of the UTLMS tropical water vapor, ENSO is more important than QBO in the upper troposphere (from $\sim 215$ to $\sim 120 \mathrm{hPa}$ ), both ENSO and QBO are important around the tropopause (from $\sim 110$ to $\sim 90 \mathrm{hPa}$ ), and mainly QBO is more important than ENSO in the lower and middle stratosphere (from $\sim 80$ to $6 \mathrm{hPa}$ ). This result is consistent with many previous studies. For example, Tweedy et al. (2017) and Diallo et al. (2018) have shown that the sudden shift in the QBO from westerly to easterly wind shear in the boreal winter of 2015-2016 significantly decreased global lower stratospheric water vapor from early spring to late autumn and reversed the lower stratosphere moistening to the lower stratosphere drying. Their results imply that QBO is more important than ENSO in modulating the lower stratospheric water vapor.

Figure 4 also shows the predicted monthly interannual tropical water vapor anomalies based on the multivariate linear regressions on the ENSO and QBO indices together (purple lines) and the differences (green lines) between the original MLS interannual monthly tropical water vapor anomalies (blue lines) and the multivariate linear regression (purple lines) at the four specific pressure levels. Figure 4 indicates that the predicted interannual monthly tropical water vapor anomalies based on the multivariate linear regressions of ENSO and QBO are very similar to the original MLS interannual monthly tropical water vapor anomalies. ENSO and
QBO together can explain about more than half $(\sim 50 \%-$ $60 \%$ ) the variance of the interannual monthly tropical water vapor anomalies under the strong assumption that the UTLMS water vapor interannual anomaly is a linear function of the ENSO or QBO index with a Gaussian distribution. However, large residues are still evident in Fig. 4, indicating that nonlinear ENSO-QBO interactions and other physical processes (e.g., BDC) as well as their interactions may be considered in order to explain the full interannual variability of the tropical UTLMS water vapor. This issue is beyond the scope of this paper and will be investigated in the future.

To highlight the different roles of ENSO and QBO phases in the interannual tropical water vapor anomalies at different pressure levels and in different seasons, Fig. 5 shows the composite interannual tropical water vapor anomalies from MLS as a function of pressure levels for winter (NDJFMA) (blue lines), summer (MJJASO) (red lines), and annual (black lines) means at four different cases based on different combinations of ENSO and QBO phases. Consistent with Figs. 3 and 4, Fig. 5 shows that ENSO mainly impacts the interannual tropical water vapor anomalies in the upper troposphere and at the tropopause, while QBO mainly affects the interannual tropical water vapor anomalies at the tropopause and in the lower and middle stratosphere. In the upper troposphere $(215-120 \mathrm{hPa})$, the interannual tropical water vapor anomalies are mainly related by the ENSO phase and its seasonal change, while the QBO's effect seems to be small. Positive interannual tropical water vapor anomalies are found during the warm ENSO phases, while negative interannual tropical water vapor anomalies are found during the cold ENSO phases for the annual, winter, and summer means no matter what the QBO phases are. However, exceptions exist for the summer and the cold easterly QBO case, but the sampling for this case is low and we have to interpret this result with caution. This is consistent with the aforementioned mechanism that ENSO impacts the upper tropospheric water vapor through the convective transport of water vapor (e.g., Jiang et al., 2015). The interannual tropical water vapor anomalies tend to be larger during the winter than during the summer because the ENSO events are usually stronger during the winter than during the summer (Wallace et al., 1998).

Near the tropopause (110-90 hPa), both ENSO and QBO as well as their season changes can influence the interannual tropical water vapor anomalies. Both warm ENSO phase and westerly QBO phase tend to cause positive interannual tropical water vapor anomalies, while cold ENSO phase and easterly QBO phase tend to cause negative interannual tropical water vapor anomalies in this layer. As a result, different interannual tropical water vapor anomalies are found for different cases depending on the different ENSO and QBO phase combinations and their seasonal variations in this layer (Liang et al., 2011). For example, very strong positive interannual tropical water vapor anomalies are found for the warm westerly case, and very strong negative interannual tropical water vapor anomalies are found for the cold easterly case 

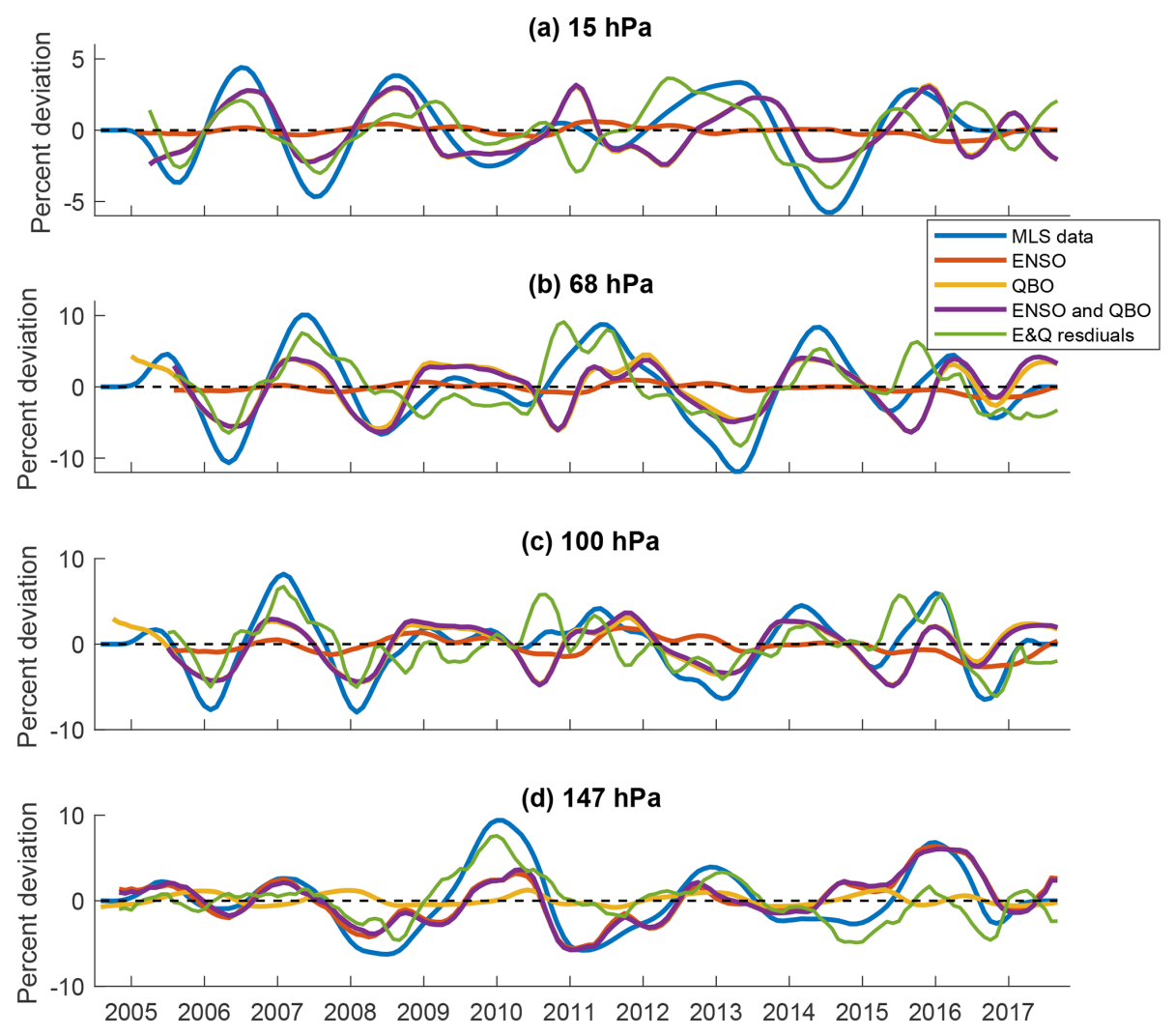

Figure 4. The time series of the monthly interannual tropical water vapor anomalies from MLS (blue lines) and the predicted monthly interannual tropical water vapor anomalies based on the linear regressions on the ENSO index only (red lines), the QBO index only (orange lines), and the ENSO and QBO indices together (purple lines) at the time lag less than 12 months with the highest $R^{2}$ value for four specific pressure levels: $15 \mathrm{hPa}(\mathbf{a}), 68 \mathrm{hPa}(\mathbf{b}), 100 \mathrm{hPa}(\mathbf{c})$, and $147 \mathrm{hPa}(\mathbf{d})$. The differences between the MLS data (blue lines) and the linear regression lines based on the ENSO and QBO together (purple lines) are also plotted (green lines).

due to the supporting effect of ENSO and QBO for the winter season. Weak interannual tropical water vapor anomalies are found for the warm easterly case and the cold westerly case due to the compensating effect of ENSO and QBO. This result is consistent with those results found by Diallo et al. (2018) and Liang et al. (2011) that emphasized the importance of the interaction of ENSO and QBO phases in controlling the tropical tropopause water vapor anomalies. However, Diallo et al. (2018) focused on the lower stratosphere, different from the tropopause layer we discussed here.

In the lower and middle stratosphere (80-6 hPa), QBO and its seasonal change contribute significantly to the interannual tropical water vapor anomalies, while the ENSO's effect is negligible. QBO explains $\sim 50 \%-60 \%$, in contrast to $\sim 2 \%$ by ENSO, of the tropical water vapor interannual variance under the strong assumption that the UTLMS water vapor interannual anomaly is a linear function of ENSO or QBO index with a Gaussian distribution. As discussed earlier, this result seems to be consistent with Tweedy et al. (2017) and Diallo et al. (2018) but not with Avery et al. (2017). During the westerly QBO phases, interannual tropical water vapor anomalies are positive near the tropopause and in the lower stratosphere (below $\sim 50 \mathrm{hPa}$ altitude), negative in the lower and middle stratosphere (between $\sim 50$ and $\sim 20 \mathrm{hPa}$ altitude), and positive again in the middle stratosphere (above $\sim 20 \mathrm{hPa}$ altitude) for all seasons. The opposite occurs during the easterly QBO phases. The sign reversals of the interannual tropical water vapor anomalies along the pressure levels in Fig. 5 are consistent with the upward-propagating water vapor anomalies and the $R^{2}$ values shown in Figs. 2 and $3 \mathrm{~b}$. There are some differences in interannual tropical water vapor anomalies between warm and cold ENSO phases and between the summer and winter seasons, but they are relatively small.

\section{Summary and conclusions}

In this study, we have analyzed the Aura MLS tropical UTLMS monthly water vapor data from 215 to $6 \mathrm{hPa}$ and from August 2004 to September 2017 using time-lag regression analysis and composite analysis to explore the interannual variations of water vapor in the whole tropical UTLMS layer and their connections to ENSO and QBO. The main findings of our analysis are summarized below. 

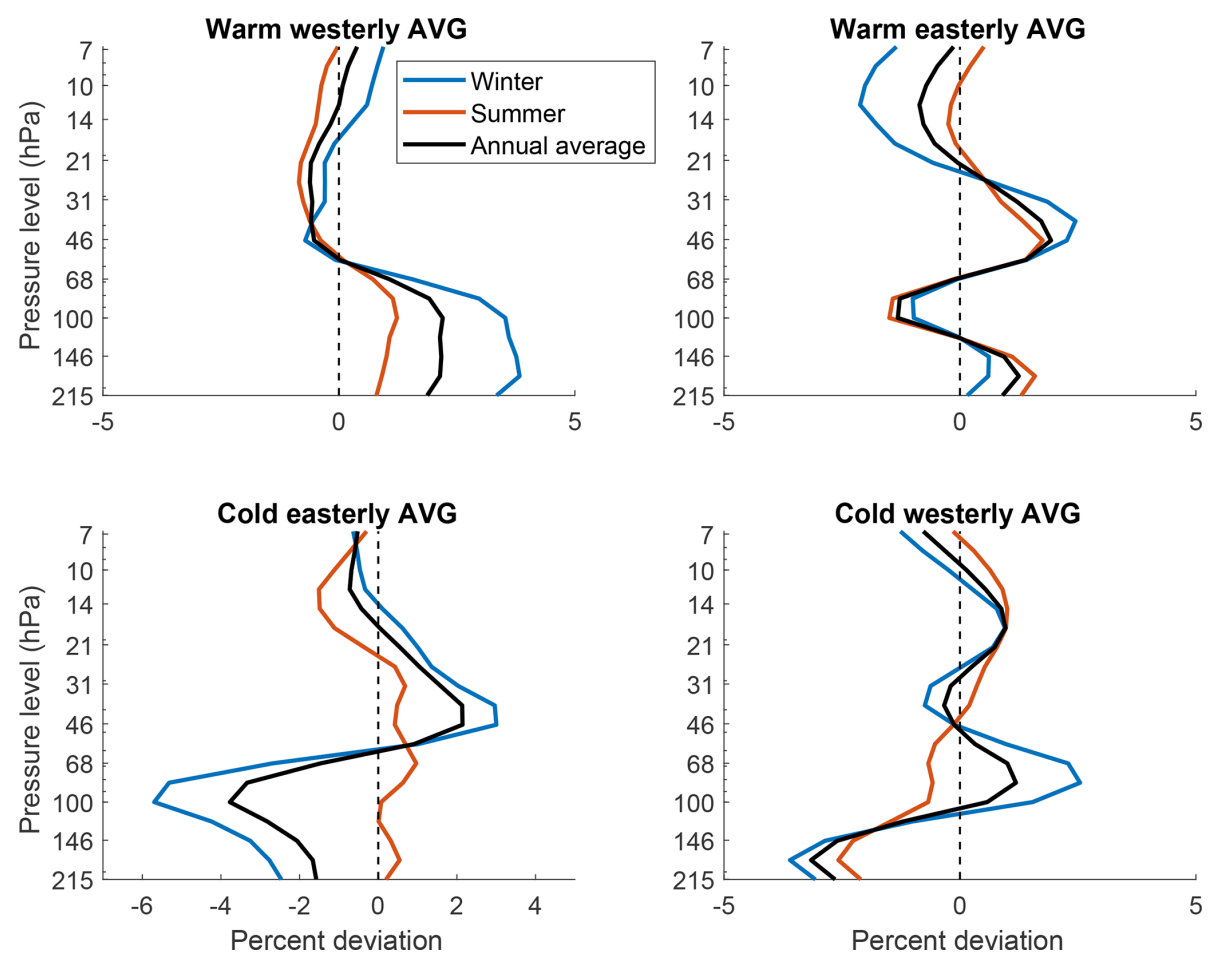

Figure 5. Composite interannual tropical water vapor anomalies from MLS at different pressure levels for winter (NDJFMA) (blue lines), summer (MJJASO) (red lines), and annual (black lines) means at four different cases based on different combinations of ENSO and QBO phases.

In the upper troposphere $(215-120 \mathrm{hPa})$, ENSO and its seasonal change contribute significantly to the interannual tropical water vapor anomalies with a $\sim 3$-month time lag, while the QBO's effect is negligible. ENSO explains $\sim 54 \%$, in contrast to $\sim 3 \%$ by $\mathrm{QBO}$, of the interannual tropical water vapor variance under the strong assumption that the UTLMS water vapor interannual anomaly is a linear function of ENSO or QBO index with a Gaussian distribution. ENSO modulates the upper tropospheric water vapor mainly through the convective transport of tropospheric water vapor and the evaporation of cloud ice. Positive interannual tropical water vapor anomalies are found during the warm ENSO phases, while negative interannual tropical water vapor anomalies are found during the cold ENSO phases for all seasons, although the interannual tropical water vapor anomalies tend to be larger during the winter than during the summer.

Near the tropopause (110-90 hPa), both ENSO and QBO as well as their seasonal changes are important for the interannual tropical water vapor anomalies. ENSO explains $\sim 8 \%$, while $\mathrm{QBO}$ explains $\sim 46 \%$ of the interannual tropical water vapor variance under the strong assumption that the UTLMS water vapor interannual anomaly is a linear function of ENSO or QBO index with a Gaussian distribution. ENSO can modulate the tropical tropopause water vapor through the convective transport of tropospheric water va- por, the evaporation of cloud ice, and its impact on the tropical tropopause temperature. In contrast, QBO modulates the tropical tropopause water vapor mainly by its modulation of the tropical tropopause temperature. Both warm ENSO phase and westerly QBO phase tend to cause positive interannual tropical water vapor anomalies, while both cold ENSO phase and easterly QBO phase tend to cause negative interannual tropical water vapor anomalies. As a result, different interannual tropical water vapor anomalies are found for different combinations of ENSO and QBO phases and their seasonal variations. For example, very strong positive interannual tropical water vapor anomalies are found for the warm westerly case and very strong negative interannual tropical water vapor anomalies are found for the cold easterly case due to the compatible effects of ENSO and QBO for the winter season. Weak interannual tropical water vapor anomalies are found for the warm easterly case and the cold westerly case due to the compensating effects of ENSO and QBO. This emphasized the importance of the interaction of ENSO and QBO phases in controlling the tropical tropopause water vapor anomalies.

In the lower and middle stratosphere (80-6 hPa), QBO and its seasonal change contribute significantly to the interannual monthly water vapor anomalies, while the ENSO's effect is negligible. QBO explains $\sim 50 \%-60 \%$, in contrast to $\sim 2 \%$ by ENSO, of the interannual tropical water vapor variance 
under the strong assumption that the UTLMS water vapor interannual anomaly is a linear function of ENSO or QBO index with a Gaussian distribution. QBO modulates the tropical lower and middle stratospheric water vapor mainly by its modulation of the tropical tropopause temperature. During the westerly QBO phase, interannual tropical water vapor anomalies are positive near the tropopause and in the lower stratosphere (below $\sim 50 \mathrm{hPa}$ altitude), negative in the lower and middle stratosphere (between $\sim 50$ and $\sim 20 \mathrm{hPa}$ altitude), and positive again in the middle stratosphere (above $\sim 20 \mathrm{hPa}$ altitude) for all seasons. The opposite occurs during the easterly QBO phase. There are some small differences in interannual tropical water vapor anomalies between warm and cold ENSO phases and between the summer and winter seasons.

In summary, ENSO has a strong impact on the interannual variations of tropical water vapor below $90 \mathrm{hPa}$ altitude, i.e., in the upper troposphere and at the tropopause. On the other hand, QBO has a large impact on the interannual variations of tropical water vapor above $110 \mathrm{hPa}$, i.e., at the tropopause and in the lower and middle stratosphere. ENSO and QBO together can explain more than half $(\sim 50 \%-60 \%)$ but not all the interannual variations of the tropical UTLMS water vapor. Nonlinear ENSO-QBO interactions and other physical processes (e.g., BDC) as well as their interactions may be considered in future investigations in order to fully explain the interannual variability of the tropical UTLMS water vapor.

The findings in the current study are generally consistent with those from previous studies (e.g., Dessler et al., 2014; Diallo et al., 2018; Ding and Fu, 2018; Liang et al., 2011; Tweedy et al., 2017; Ye et al., 2018). However, the relative roles of ENSO and QBO in the tropical UTLMS water vapor interannual variabilities for the entire UTLMS layer and at different phase lags and different pressure levels are more completely investigated in the current study than the previous ones. In addition, this study provides direct empirical evidence to support a belief that the QBO impacts the tropical UTLMS water vapor mainly through its influence on the tropical tropopause temperature. These results can serve as an important benchmark for future climate model evaluation studies.

Data availability. The MLS water vapor data used in this research are freely available through the Aura MLS project website (https:// mls.jpl.nasa.gov, last access: 5 August 2019, Read et al., 2017). The multivariate ENSO indices used in this research are freely available from the NOAA Earth System Research Laboratory (ESRL) website (https://www.esrl.noaa.gov/psd/enso/mei/data/meiv2.data, last access: 5 August 2019, Wolter and Timlin, 2011). The $50 \mathrm{hPa}$ QBO indices used in this research are also freely available from the NOAA NCEP Climate Prediction Center (CPC) website (http: //www.cpc.ncep.noaa.gov/data/indices/qbo.u50.index, last access: 5 August 2019).
Author contributions. JHJ, HS, and BT designed this study. EWT performed the data analysis and prepared the figures. All the authors contributed to the discussion of the results and the preparation of the manuscript.

Competing interests. The authors declare that they have no conflict of interest.

Acknowledgements. This research was performed at the Jet Propulsion Laboratory, California Institute of Technology (Caltech), under a contract with the National Aeronautics and Space Administration. The authors thank Andrew Dessler, Michaela Hegglin, and two anonymous referees for their constructive and insightful comments that helped to improve the quality of this paper. The first author also thanks Matthew Worden for his help with the MATLAB code.

Financial support. This research has been supported by the Aura Microwave Limb Sounder project at JPL.

Review statement. This paper was edited by Gabriele Stiller and reviewed by two anonymous referees.

\section{References}

Avery, M. A., Davis, S. M., Rosenlof, K. H., Ye, H., and Dessler, A. E.: Large anomalies in lower stratospheric water vapour and ice during the 2015-2016 El Nino, Nature Geosci., 10, 405-409, https://doi.org/10.1038/ngeo2961, 2017.

Baldwin, M. P., Gray, L. J., Dunkerton, T. J., Hamilton, K., Haynes, P. H., Randel, W. J., Holton, J. R., Alexander, M. J., Hirota, I., Horinouchi, T., Jones, D. B. A., Kinnersley, J. S., Marquardt, C., Sato, K., and Takahashi, M.: The quasi-biennial oscillation, Rev. Geophys., 39, 179-229, https://doi.org/10.1029/1999rg000073, 2001.

Brewer, A. W.: Evidence for a world circulation provided by the measurements of helium and water vapour distribution in the stratosphere, Q. J. Roy. Meteor. Soc., 75, 351-363, https://doi.org/10.1002/qj.49707532603, 1949.

Butchart, N.: The Brewer-Dobson circulation, Rev. Geophys., 52, 157-184, https://doi.org/10.1002/2013rg000448, 2014.

Calvo, N., Garcia, R. R., Randel, W. J., and Marsh, D R.: Dynamical Mechanism for the Increase in Tropical Upwelling in the Lowermost Tropical Stratosphere during Warm ENSO Events, J. Atmos. Sci., 67, 2331-2340, https://doi.org/10.1175/2010jas3433.1, 2010.

Choi, W., Lee, H., Grant, W. B., Park, J. H., Holton, J. R., Lee, K. M., and Naujokat, B.: On the secondary meridional circulation associated with the quasi-biennial oscillation, Tellus B, 54, 395406, https://doi.org/10.1034/j.1600-0889.2002.201286.x, 2002.

Dessler, A. E., Schoeberl, M. R., Wang, T., Davis, S. M., and Rosenlof, K. H.: Stratospheric water vapor feedback, P. Nat. Acad. Sci. USA, 110, 18087-18091, https://doi.org/10.1073/pnas.1310344110, 2013. 
Dessler, A. E., Schoeberl, M. R., Wang, T., Davis, S. M., Rosenlof, K. H., and Vernier, J. P.: Variations of stratospheric water vapor over the past three decades, J. Geophys. Res., 119, 12588-12598, https://doi.org/10.1002/2014jd021712, 2014.

Diallo, M., Riese, M., Birner, T., Konopka, P., Müller, R., Hegglin, M. I., Santee, M. L., Baldwin, M., Legras, B., and Ploeger, F.: Response of stratospheric water vapor and ozone to the unusual timing of El Niño and the QBO disruption in 2015-2016, Atmos. Chem. Phys., 18, 13055-13073, https://doi.org/10.5194/acp-1813055-2018, 2018.

Ding, Q. H. and Fu, Q.: A warming tropical central Pacific dries the lower stratosphere, Clim. Dynam., 50, 2813-2827, https://doi.org/10.1007/s00382-017-3774-y, 2018.

Flury, T., Wu, D. L., and Read, W. G.: Correlation among cirrus ice content, water vapor and temperature in the TTL as observed by CALIPSO and Aura/MLS, Atmos. Chem. Phys., 12, 683-691, https://doi.org/10.5194/acp-12-683-2012, 2012.

Forster, P. M. D. and Shine, K. P.: Stratospheric water vapour changes as a possible contributor to observed stratospheric cooling, Geophys. Res. Lett., 26, 3309-3312, https://doi.org/10.1029/1999GL010487, 1999.

Fueglistaler, S. and Haynes, P. H.: Control of interannual and longer-term variability of stratospheric water vapor, J. Geophys. Res., 110, D24108, https://doi.org/10.1029/2005jd006019, 2005.

Fueglistaler, S., Dessler, A. E., Dunkerton, T. J., Folkins, I., Fu, Q., and Mote, P. W.: Tropical tropopause layer, Rev. Geophys., 47, RG1004, https://doi.org/10.1029/2008rg000267, 2009.

Fujiwara, M., Vomel, H., Hasebe, F., Shiotani, M., Ogino, S. Y., Iwasaki, S., Nishi, N., Shibata, T., Shimizu, K., Nishimoto, E., Canossa, J. M. V., Selkirk, H. B., and Oltmans, S. J.: Seasonal to decadal variations of water vapor in the tropical lower stratosphere observed with balloon-borne cryogenic frost point hygrometers, J. Geophys. Res., 115, D18304, https://doi.org/10.1029/2010jd014179, 2010.

Geller, M. A., Zhou, X. L., and Zhang, M. H.: Simulations of the interannual variability of stratospheric water vapor, J. Atmos. Sci., 59, 1076-1085, https://doi.org/10.1175/15200469(2002)059<1076:Sotivo>2.0.Co;2, 2002.

Gettelman, A., Randel, W. J., Massie, S., Wu, F., Read, W. G., and Russell, J. M.: El Nino as a natural experiment for studying the tropical tropopause region, J. Climate, 14, 3375-3392, https://doi.org/10.1175/15200442(2001)014<3375:enoaan>2.0.co;2, 2001.

Hegglin, M. I., Tegtmeier, S., Anderson, J., Froidevaux, L., Fuller, R., Funke, B., Jones, A., Lingenfelser, G., Lumpe, J., Pendlebury, D., Remsberg, E., Rozanov, A., Toohey, M., Urban, J., von Clarmann, T., Walker, K. A., Wang, R., and Weigel, K.: SPARC Data Initiative: Comparison of water vapor climatologies from international satellite limb sounders, J. Geophys. Res., 118, 1182411846, https://doi.org/10.1002/jgrd.50752, 2013.

Hegglin, M. I., Plummer, D. A., Shepherd, T. G., Scinocca, J. F., Anderson, J., Froidevaux, L., Funke, B., Hurst, D., Rozanov, A., Urban, J., von Clarmann, T., Walker, K. A., Wang, H. J., Tegtmeier, S., and Weigel, K.: Vertical structure of stratospheric water vapour trends derived from merged satellite data, Nat. Geosci., 7, 768-776, https://doi.org/10.1038/ngeo2236, 2014.

Held, I. M. and Soden, B. J.: Water vapor feedback and global warming, Annu. Rev. Energ. Env., 25, 441-475, https://doi.org/10.1146/annurev.energy.25.1.441, 2000.
Huang, B., L'Heureux, M., Hu, Z.-Z., and Zhang, H.-M.: Ranking the strongest ENSO events while incorporating SST uncertainty, Geophys. Res. Lett., 43, 9165-9172, https://doi.org/10.1002/2016gl070888, 2016.

Jiang, J. H., Su, H., Zhai, C. X., Perun, V. S., Del Genio, A., Nazarenko, L. S., Donner, L. J., Horowitz, L., Seman, C., Cole, J., Gettelman, A., Ringer, M. A., Rotstayn, L., Jeffrey, S., Wu, T. W., Brient, F., Dufresne, J. L., Kawai, H., Koshiro, T., Watanabe, M., Lecuyer, T. S., Volodin, E. M., Iversen, T., Drange, H., Mesquita, M. D. S., Read, W. G., Waters, J. W., Tian, B. J., Teixeira, J., and Stephens, G. L.: Evaluation of cloud and water vapor simulations in CMIP5 climate models using NASA "A-Train" satellite observations, J. Geophys. Res., 117, D14105, https://doi.org/10.1029/2011jd017237, 2012.

Jiang, J. H., Su, H., Zhai, C. X., Wu, L. T., Minschwaner, K., Molod, A. M., and Tompkins, A. M.: An assessment of upper troposphere and lower stratosphere water vapor in MERRA, MERRA2, and ECMWF reanalyses using Aura MLS observations, J. Geophys. Res., 120, 11468-11485, https://doi.org/10.1002/2015jd023752, 2015.

Kawatani, Y., Lee, J. N., and Hamilton, K.: Interannual Variations of Stratospheric Water Vapor in MLS Observations and Climate Model Simulations, J. Atmos. Sci., 71, 4072-4085, https://doi.org/10.1175/jas-d-14-0164.1, 2014.

Kiladis, G. N., Straub, K. H., Reid, G. C., and Gage, K. S.: Aspects of interannual and intraseasonal variability of the tropopause and lower stratosphere, Q. J. Roy. Meteor. Soc., 127, 1961-1983, https://doi.org/10.1256/smsqj.57605, 2001.

Konopka, P., Ploeger, F., Tao, M. C., and Riese, M.: Zonally resolved impact of ENSO on the stratospheric circulation and water vapor entry values, J. Geophys. Res., 121, 11486-11501, https://doi.org/10.1002/2015jd024698, 2016.

Lambert, A., Read, W. G., Livesey, N. J., Santee, M. L., Manney, G. L., Froidevaux, L., Wu, D. L., Schwartz, M. J., Pumphrey, H. C., Jimenez, C., Nedoluha, G. E., Cofield, R. E., Cuddy, D. T., Daffer, W. H., Drouin, B. J., Fuller, R. A., Jarnot, R. F., Knosp, B. W., Pickett, H. M., Perun, V. S., Snyder, W. V., Stek, P. C., Thurstans, R. P., Wagner, P. A., Waters, J. W., Jucks, K. W., Toon, G. C., Stachnik, R. A., Bernath, P. F., Boone, C. D., Walker, K. A., Urban, J., Murtagh, D., Elkins, J. W., and Atlas, E.: Validation of the Aura Microwave Limb Sounder middle atmosphere water vapor and nitrous oxide measurements, J. Geophys. Res., 112, D24S36, https://doi.org/10.1029/2007jd008724, 2007.

Liang, C. K., Eldering, A., Gettelman, A., Tian, B., Wong, S., Fetzer, E. J., and Liou, K. N.: Record of tropical interannual variability of temperature and water vapor from a combined AIRS-MLS data set, J. Geophys. Res., 116, D06103, https://doi.org/10.1029/2010jd014841, 2011.

Liess, S. and Geller, M. A.: On the relationship between QBO and distribution of tropical deep convection, J. Geophys. Res., 117, D03108, https://doi.org/10.1029/2011jd016317, 2012.

Lindzen, R. S. and Holton, J. R.: A theory of quasi-biennial oscillation, J. Atmos. Sci., 25, 1095-1107, https://doi.org/10.1175/15200469(1968)025<1095:atotqb>2.0.co;2, 1968.

Liu, R., Su, H., Liou, K. N., Jiang, J. H., Gu, Y., Liu, S. C., and Shiu, C. J.: An Assessment of Tropospheric Water Vapor Feedback Using Radiative Kernels, J. Geophys. Res., 123, 14991509, https://doi.org/10.1002/2017jd027512, 2018. 
Livesey, N. J.: EOS Aura MLS Version 4.2x Level 2 data quality and description document, Tech. Rep., D-33509, Rev. A, Jet Propulsion Laboratory, California Institute of Technology, 2015.

Mote, P. W., Rosenlof, K. H., McIntyre, M. E., Carr, E. S., Gille, J. C., Holton, J. R., Kinnersley, J. S., Pumphrey, H. C., Russell, J. M., and Waters, J. W.: An atmospheric tape recorder: The imprint of tropical tropopause temperatures on stratospheric water vapor, J. Geophys. Res., 101, 3989-4006, https://doi.org/10.1029/95jd03422, 1996.

Newman, P. A., Coy, L., Pawson, S., and Lait, L. R.: The anomalous change in the QBO in 2015-2016, Geophys. Res. Lett., 43, 87918797, https://doi.org/10.1002/2016g1070373, 2016.

Osprey, S. M., Butchart, N., Knight, J. R., Scaife, A. A., Hamilton, K., Anstey, J. A., Schenzinger, V., and Zhang, C. X.: An unexpected disruption of the atmospheric quasi-biennial oscillation, Science, 353, 1424-1427, https://doi.org/10.1126/science.aah4156, 2016.

Philander, S. G. H.: El Nino, La Nina, and the Southern Oscillation, International Geophysical Series, Academic Press, San Diego, CA, USA, 293 pp., 1990.

Randel, W. J., Wu, F., Oltmans, S. J., Rosenlof, K., and Nedoluha, G. E.: Interannual changes of stratospheric water vapor and correlations with tropical tropopause temperatures, J. Atmos. Sci., 61, 2133-2148, https://doi.org/10.1175/15200469(2004)061<2133:icoswv>2.0.co;2, 2004.

Randel, W. J., Wu, F., Vomel, H., Nedoluha, G. E., and Forster, P.: Decreases in stratospheric water vapor after 2001: Links to changes in the tropical tropopause and the Brewer-Dobson circulation, J. Geophys. Res., 111, D12312, https://doi.org/10.1029/2005jd006744, 2006.

Randel, W. J., Garcia, R. R., Calvo, N., and Marsh, D.: ENSO influence on zonal mean temperature and ozone in the tropical lower stratosphere, Geophys. Res. Lett., 36, L15822, https://doi.org/10.1029/2009gl039343, 2009.

Randel, W. J. and Jensen, E. J.: Physical processes in the tropical tropopause layer and their roles in a changing climate, Nat. Geosci., 6, 169-176, https://doi.org/10.1038/ngeo1733, 2013.

Read, W. G., Lambert, A., Bacmeister, J., Cofield, R. E., Christensen, L. E., Cuddy, D. T., Daffer, W. H., Drouin, B. J., Fetzer, E., Froidevaux, L., Fuller, R., Herman, R., Jarnot, R. F., Jiang, J. H., Jiang, Y. B., Kelly, K., Knosp, B. W., Kovalenko, L. J., Livesey, N. J., Liu, H. C., Manney, G. L., Pickett, H. M., Pumphrey, H. C., Rosenlof, K. H., Sabounchi, X., Santee, M. L., Schwartz, M. J., Snyder, W. V., Stek, P. C., Su, H., Takacs, L. L., Thurstans, R. P., Vomel, H., Wagner, P. A., Waters, J. W., Webster, C. R., Weinstock, E. M., and Wu, D. L.: Aura Microwave Limb Sounder upper tropospheric and lower stratospheric $\mathrm{H}_{2} \mathrm{O}$ and relative humidity with respect to ice validation, J. Geophys. Res., 112, D24S35, https://doi.org/10.1029/2007jd008752, 2007.

Riese, M., Ploeger, F., Rap, A., Vogel, B., Konopka, P., Dameris, M., and Forster, P.: Impact of uncertainties in atmospheric mixing on simulated UTLS composition and related radiative effects, J. Geophys. Res., 117, D16305, https://doi.org/10.1029/2012jd017751, 2012.

Schwartz, M. J., Waliser, D. E., Tian, B., Wu, D. L., Jiang, J. H., and Read, W. G.: Characterization of MJO-related upper tropospheric hydrological processes using MLS, Geophys. Res. Lett., 35, L08812, https://doi.org/10.1029/2008gl033675, 2008.
Soden, B. J. and Held, I. M.: An assessment of climate feedbacks in coupled ocean-atmosphere models, J. Climate, 19, 3354-3360, https://doi.org/10.1175/jcli3799.1, 2006.

Soden, B. J., Held, I. M., Colman, R., Shell, K. M., Kiehl, J. T., and Shields, C. A.: Quantifying climate feedbacks using radiative kernels, J. Climate, 21, 3504-3520, https://doi.org/10.1175/2007jcli2110.1, 2008.

Solomon, S., Rosenlof, K. H., Portmann, R. W., Daniel, J. S., Davis, S. M., Sanford, T. J., and Plattner, G. K.: Contributions of Stratospheric Water Vapor to Decadal Changes in the Rate of Global Warming, Science, 327, 1219-1223, https://doi.org/10.1126/science.1182488, 2010.

Su, H., Neelin, J. D., and Meyerson, J. E.: Mechanisms for lagged atmospheric response to ENSO SST forcing, J. Climate, 18, 4195-4215, https://doi.org/10.1175/jcli3514.1, 2005.

Su, H., Read, W. G., Jiang, J. H., Waters, J. W., Wu, D. L., and Fetzer, E. J.: Enhanced positive water vapor feedback associated with tropical deep convection: New evidence from Aura MLS, Geophys. Res. Lett., 33, L05709, https://doi.org/10.1029/2005g1025505, 2006.

$\mathrm{Su}, \mathrm{H}$. and Jiang, J. H.: Tropical Clouds and Circulation Changes during the 2006/07 and 2009/10 El Ninos, J. Climate, 26, 399413, https://doi.org/10.1175/jcli-d-12-00152.1, 2013.

Takahashi, H., Su, H., and Jiang, J. H.: Error analysis of upper tropospheric water vapor in CMIP5 models using "A-Train" satellite observations and reanalysis data, Clim. Dynam., 46, 2787-2803, https://doi.org/10.1007/s00382-015-2732-9, 2016.

Tao, M. C., Konopka, P., Ploeger, F., Riese, M., Muller, R., and Volk, C. M.: Impact of stratospheric major warmings and the quasi-biennial oscillation on the variability of stratospheric water vapor, Geophys. Res. Lett., 42, 4599-4607, https://doi.org/10.1002/2015gl064443, 2015.

Tian, B., Soden, B. J., and Wu, X. Q.: Diurnal cycle of convection, clouds, and water vapor in the tropical upper troposphere: Satellites versus a general circulation model, J. Geophys. Res., 109, D10101, https://doi.org/10.1029/2003jd004117, 2004.

Tian, B., Waliser, D. E., Fetzer, E. J., Lambrigtsen, B. H., Yung, Y. L., and Wang, B.: Vertical moist thermodynamic structure and spatial-temporal evolution of the MJO in AIRS observations, J. Atmos. Sci., 63, 2462-2485, https://doi.org/10.1175/jas3782.1, 2006.

Tian, B., Yung, Y. L., Waliser, D. E., Tyranowski, T., Kuai, L., Fetzer, E. J., and Irion, F. W.: Intraseasonal variations of the tropical total ozone and their connection to the Madden-Julian Oscillation, Geophys. Res. Lett., L08704, https://doi.org/10.1029/2007gl029451, 2007.

Tian, B., Waliser, D. E., Fetzer, E. J., and Yung, Y. L.: Vertical moist thermodynamic structure of the Madden-Julian Oscillation in Atmospheric Infrared Sounder retrievals: An update and a comparison to ECMWF Interim Re-Analysis, Mon. Weather Rev., 138, 4576-4582, https://doi.org/10.1175/2010mwr3486.1, 2010.

Tian, B., Waliser, D. E., Kahn, R. A., and Wong, S.: Modulation of Atlantic aerosols by the Madden-Julian Oscillation, J. Geophys. Res., 116, D15108, https://doi.org/10.1029/2010jd015201, 2011.

Tweedy, O. V., Kramarova, N. A., Strahan, S. E., Newman, P. A., Coy, L., Randel, W. J., Park, M., Waugh, D. W., and Frith, S. M.: Response of trace gases to the disrupted 2015-2016 quasi-biennial oscillation, Atmos. Chem. Phys., 17, 6813-6823, https://doi.org/10.5194/acp-17-6813-2017, 2017. 
Uma, K. N., Das, S. K., and Das, S. S.: A climatological perspective of water vapor at the UTLS region over different global monsoon regions: observations inferred from the Aura-MLS and reanalysis data, Clim. Dynam., 43, 407-420, https://doi.org/10.1007/s00382-014-2085-9, 2014.

Wallace, J. M., Rasmusson, E. M., Mitchell, T. P., Kousky, V. E., Sarachik, E. S., and von Storch, H.: The structure and evolution of ENSO-related climate variability in the tropical Pacific: Lessons from TOGA, J. Geophys. Res., 103, 14241-14259, https://doi.org/10.1029/97jc02905, 1998.

Wolter, K. and Timlin, M. S.: El Nino/Southern Oscillation behaviour since 1871 as diagnosed in an extended multivariate ENSO index (MEI.ext), Int. J. Clim., 31, 1074-1087, https://doi.org/10.1002/joc.2336, 2011.

Wu, L., Su, H., Jiang, J. H., and Read, W. G.: Hydration or dehydration: competing effects of upper tropospheric cloud radiation on the TTL water vapor, Atmos. Chem. Phys., 12, 7727-7735, https://doi.org/10.5194/acp-12-7727-2012, 2012.
Ye, H., Dessler, A. E., and Yu, W.: Effects of convective ice evaporation on interannual variability of tropical tropopause layer water vapor, Atmos. Chem. Phys., 18, 4425-4437, https://doi.org/10.5194/acp-18-4425-2018, 2018.

Zhou, X. L., Geller, M. A., and Zhang, M. H.: Tropical cold point tropopause characteristics derived from ECMWF reanalyses and soundings, J. Climate, 14, 1823-1838, https://doi.org/10.1175/15200442(2001)014<1823:tcptcd>2.0.co;2, 2001.

Zhou, X. L., Geller, M. A., and Zhang, M. H.: Temperature fields in the tropical tropopause transition layer, J. Climate, 17, 2901-2908, https://doi.org/10.1175/15200442(2004)017<2901:tfittt>2.0.co;2, 2004. 